\title{
Colchicum cupanii Guss. subsp. glossophyllum (Heldr.) Rouy, Datura innoxia Mill. and Eclipta prostrata (L.) L., new floristic records in Montenegro and western Balkan
}

\author{
Danka Caković ${ }^{1 *}$, DaniJela SteŠEvić ${ }^{1}$, Snežana Vuksanović ${ }^{2}$, Kit TaN $^{3}$ \\ ${ }^{1}$ University of Montenegro, Faculty of Science, Department of Biology, \\ Dzordza Vashingtona bb, 81000 Podgorica, Montenegro \\ ${ }^{2}$ Natural History Museum of Montenegro, Trg Vojvode Bećir Bega Osmanagića, \\ 81000 Podgorica, Montenegro \\ ${ }^{3}$ Institute of Biology, University of Copenhagen, Øster Farimagsgade 2D, \\ DK-1353 Copenhagen K, Denmark
}

\begin{abstract}
During field investigations on Long Ulcinj Beach, Montenegrin coast, three taxa new to Montenegrin flora were collected: Colchicum cupanii Guss. subsp. glossophyllum (Heldr.) Rouy, Datura innoxia Mill. and Eclipta prostrata (L.) L. The first species is native to Europe, while the others are alien. Colchicum cupanii subsp. glossophyllum is an endemic of the Balkan Peninsula, with a distribution formerly restricted to Greece and Albania, so this new record extends its distribution to the north-west. The distribution of Eclipta prostrata in the Balkans is also enlarged by this new record for Montenegro, in a westerly direction.
\end{abstract}

Key words: Balkan, Colchicum cupanii, Datura innoxia, Eclipta prostrata, flora, Montenegro

\section{Introduction}

If the richness of the flora of an area is expressed by the ratio of number of species per square meter, Montenegro has the richest flora of all European countries (STEVANOvić et al. 1995). The number of species and subspecies of vascular plants in Montenegro exceeds 3600 (Rohlena 1942, Pulević 2005, STEŠEvić et al. 2008). The flora of some parts of the country is not comprehensively known, or is not fully documented for all seasons, so new records are not uncommon in the country (GuTERMAN 2012, PETROVIĆ and STEŠEvić 2011). Accordingly the number of 3600 vascular plant taxa may yet prove to be an underestimation for Montenegro.

* Corresponding author, e-mail: danka.petrovic@t-com.me

Copyright $^{\circledR} 2014$ by Acta Botanica Croatica, the Faculty of Science, University of Zagreb. All rights reserved. 
Between April 2010 and November 2012 several field trips were undertaken in the coastal part of Montenegro, with the goal of filling floristic gaps in former investigations and searching for additions to the flora of Montenegro. The most interesting data were gathered during the survey of the Long Ulcinj Beach and its hinterland and form the subject of this paper. This coastal region has attracted the attention of botanists since the beginning of the $19^{\text {th }}$ century (RohlenA 1942, PUlEvić 1976, BleČIĆ and Pulević 1979, TrinAJSTIĆ 1989, Mujović 1994, LAKušić et al. 2004, Petrović and Vuksanović 2005, Vuksanović and PeTROVIĆ 2007), but due to absence of continual and systematic investigations its flora is still incompletely known.

\section{Material and methods}

Plant material was collected during field investigations of the Montenegrin coast, in period from April 2010 to November 2012. Each location where plants were recorded were geo-coded by using a GPS device Garmin e-Trex Vista C. Field data about the habitats, population size and threat assessments for each species were also obtained. Voucher specimens were deposited in the TGU (voucher numbers 319392-319396) and in the Herbarium Collection of the Natural History Museum of Montenegro (voucher numbers 4082-4085). Identification of materials was conducted according to Rouy (1905), TuTin et al. (1972, 1976), Pignatti (1982) and PERSSON (2007). The climate of the area is presented by the Walter climate diagram (Fig. 1) and additional climatic data have been obtained from the weather reporting station in Ulcinj, for the period 1961-1990. NATURA 2000 habitats are adjusted according to the Interpretation manual of European Union habitats (EUROPEAN COMMISSION

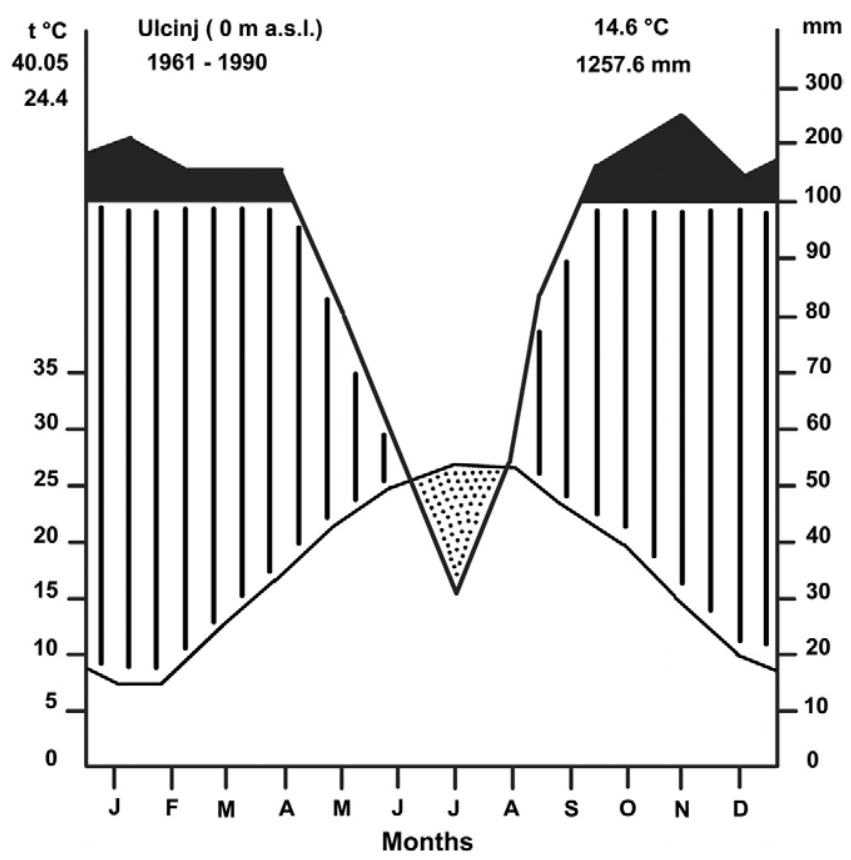

Fig. 1. Walter climate diagram of Ulcinj. 
DireCtORATES GENERAL 2007). Red list was specified according to the IUCN criteria (IUCN 2011). The index of floristic richness is expressed by the ratio $\log N / \log A$ ( $\log$ of the number of species and subspecies/log of the surface area).

\section{Study area}

At approximately $12 \mathrm{~km}$, Long Ulcinj Beach is the longest beach on the Adriatic coast, at the south-eastern end of which it is located (Fig. 2). This area is bordered by the channel of Port Milena to the west and the Bojana River to the east. It belongs to the wide Ulcinj plain, frequently exposed to very strong winds that carry sand from the shore inland, so sand covers a major part of the area (MiJović 1994).

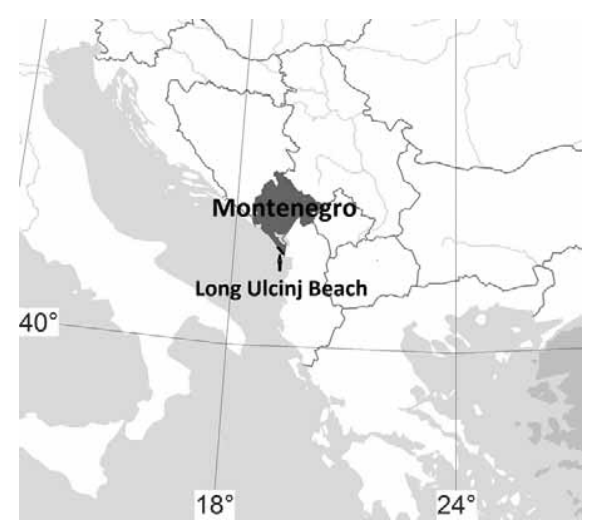

Fig. 2. Geographical position of Long Ulcinj Beach (basic map: afe_basemap, with permission of the Atlas Florae Europaea).

The average width of the beach and the hinterland is $1.5 \mathrm{~km}$, and the northern border is the regional road. Within the area of Long Beach, Quaternary formations are strongly developed, represented by alluvial formations and sands on the beaches. Alluvial sediments develop in the estuary of the Bojana River and in larger parts of Long Beach, where the alluvium is made of pebbles, sand, mud and sand-clay, i.e. materials which form the catchment area. Sandy beach sediments form on places where the sea penetrates softer rocks and creates space for the accumulation of the result of the erosion of these rocks. These are present along the length of Long Beach. The climate is of the Mediterranean type, characterized by cool, wet winters and hot, dry summers (Fig. 1). In some years July and August are completely without rainfall. According to investigations ten NATURA 2000 habitats were recorded: Annual vegetation of drift lines (1210), Mediterranean salt meadows (Juncetalia maritime 1410), Embryonic shifting dunes (2110), Shifting dunes along the shoreline with Ammophila arenaria (white dunes 2120), Humid dune slacks (2190), Dunes with Euphorbia terracina (2220), Brachypodietalia dune grasslands with annuals (2240), Wooded dunes with Pinus pinea and/or Pinus pinaster (2270), Mediterranean temporary ponds (3170), and Salix alba and Populus alba galleries (92A0). In addition a number of anthropogenically modified habitats are present. This great habitat diversity results in huge floristic richness. 


\section{Results and discussion}

During field investigations of the coastal part of Montenegro, three new taxa for Montenegrin flora were collected on Long Ulcinj Beach: Colchicum cupanii Guss. subsp. glossophyllum (Heldr.) Rouy, Datura innoxia Mill. and Eclipta prostrata (L.) L.

\section{Colchicum cupanii Guss. subsp. glossophyllum (Heldr.) Rouy}

In the field survey conducted at the beginning of November 2012, one unfamiliar Colchicum species, producing leaves and flowers together, was found (Fig. 3).

Prior to this investigation, the only Colchicum species in Montenegro that were known to produce postfloral leaves were $C$. autumnale L., C. bivonae Guss, and C. haynaldii Heuff. (Rohlena 1942, Pulević 2005). After detailed study of the collected material, the plant was confirmed as Colchicum cupanii subsp. glossophyllum (RouY 1905; PERSSON 2007, personal communication).

In the European flora Colchicum cupanii is represented by two subspecies: cupanii and glossophyllum. The distribution of the typical subspecies cupanii is in the Apennine, $\mathrm{S}$ France, Cyclades, S Aegean islands, and NW Africa, while the subspecies glossophyllum is considered an endemic of the Balkan Peninsula, with a distribution restricted to Greece and Albania (EURO+MED, 2006-). Accordingly, this new record extends the known distribution area to the north-west.

On Long Ulcinj Beach C. cupanii subsp. glossophyllum was recorded in three localities, placed in the belt transect of $1.5 \mathrm{~km}$. In each case the substrate was sandy, but the habitat type differed. In the first locality (N 41 54 ' 33”, E $19^{\circ} 15^{\prime} 23.3$ ”), four individuals of Colchicum were present. The habitat was identified as NATURA 2000 - 2270 Wooded dunes with Pinus pinea and/or Pinus pinaster. In the tree layer the dominant species were Pinus halepensis Miller. and Pinus pinaster Aiton, while in the shrub and herb layer the following species were common: Quercus coccifera L., Myrtus comminus L., Smilax aspera

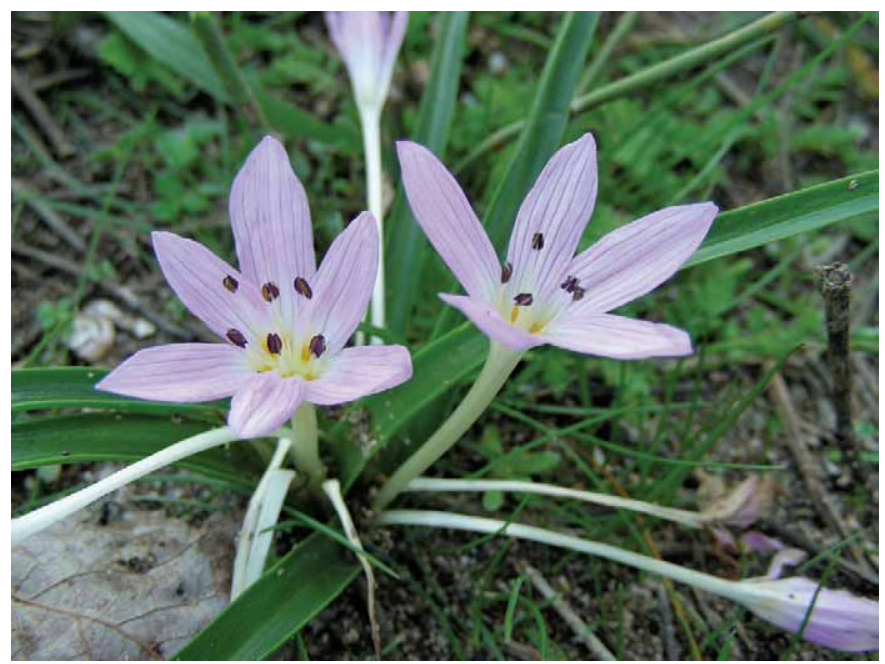

Fig. 3. Colchicum cupanii subsp. glossophyllum (photo: D. Stešević). 
L., Crataegus monogyna Jacq., Rubus ulmifolius Schott., Ruscus aculeatus L., Asparagus acutifolius L., Pteridium aguilinum L. In the vicinity of the Colchicum individuals, species such as Stellaria media (L.) Cirillo, Teucrium capitatum L., Teucrium chamaedrys L., Geranium purpureum Vill., Geranium villosum Ten., Holoschoenus vulgaris Link, Verbascum sinuatum $\mathrm{L}$. were found.

In a second locality (distant ca $300 \mathrm{~m}$ from the first locality), up to 10 individuals of this plant were recorded as constituenst of roadside vegetation on the border with the NATURA 2000 habitat 2270 Wooded dunes with Pinus pinea and/or Pinus pinaster. Accompanying species: Erodium cicutarium (L.) L'Hér, Tunica saxifraga (L.) Scop., Medicago arabica (L.) Huds., Helianthemum obscurum Pers., Alkanna tinctoria Tausch, Asphodelus microcarpus Viv.

The third locality (N 41 $53^{\prime} 18.6^{\prime \prime}$, E $\left.19^{\circ} 18^{\prime} 52.7^{\prime \prime}\right)$ was also near the local road, but next to the fringe of a humid dune slack (NATURA 2000 habitat 2190). The number of individuals was up to 10. Accompanying species: Ephedra distachya L., Artemisia campestris L., Erodium cicutarium, Tunica saxifraga, Cynodon dactylon (L.) Pers.

Voucher specimens:

MONTENEGRO: Long Ulcinj Beach N 41 ' 54' 33”, E 19 15' 23.3”, 10 m a.s.1., 2270 Wooded dunes with Pinus pinea and/or Pinus pinaster, (Caković, D., Stešević, D., 2.11. 2012., TGU- 319392); Long Ulcinj Beach N 41 54' 12”, E 19 16' 11.2”, 10 m a.s.1., 2270 Wooded dunes with Pinus pinea and/or Pinus pinaster, (Caković, D., Stešević, D., 2.11. 2012., TGU- 319393); Long Ulcinj Beach N 41 53' 18.6”, E 19 18' 52.7”, 15 m a.s.1., 2190 Humid dune slack, (Vuksanović, S., Stešević, D., Caković, D. 9.11.2012., TGU319394).

\section{Threats, endangered status and protection}

In the last 10 years Long Ulcinj Beach and its hinterland has been exposed to intensive anthropogenic pressure, mainly tourism development and urbanization. In order to improve tourist facilities, the construction of buildings, roads, parking places and beach furniture has intensified. In some cases small buildings are constructed right on the beach sand. This has resulted in an increase of waste and the spread of alien species. Taking into account all the named threats, the survival of this species is questionable, and the authors recommend its protection by national legislation. The population numbers less than 50 mature individuals, thus applying the IUCN Red list categories and criteria (IUCN 2011) and Red list categories and criteria at the regional level (IUCN 2003) the current national status of Colchicum cupanii subsp. glossophyllum in Montenegro is critically endangered (CR D1).

\section{Datura innoxia Miller}

In May 2010, on waste ground in the hinterland of Long Ulcinj Beach (N 41 ${ }^{\circ} 53$ ' 52.2”, E $19^{\circ} 17^{\prime} 58.2^{\prime}$, Fig. 4) a couple of individuals of Datura, with significantly bigger flowers and more grayish appearance than neighboring individuals of Datura stramonium L., were collected.

This species was identified as Datura innoxia. Identification was confirmed during the fruiting period. The capsule was egg shaped, directed downwards and three $\mathrm{cm}$ in diameter, with numerous slender and spines of almost equal-length up to four $\mathrm{mm}$. In the same local- 


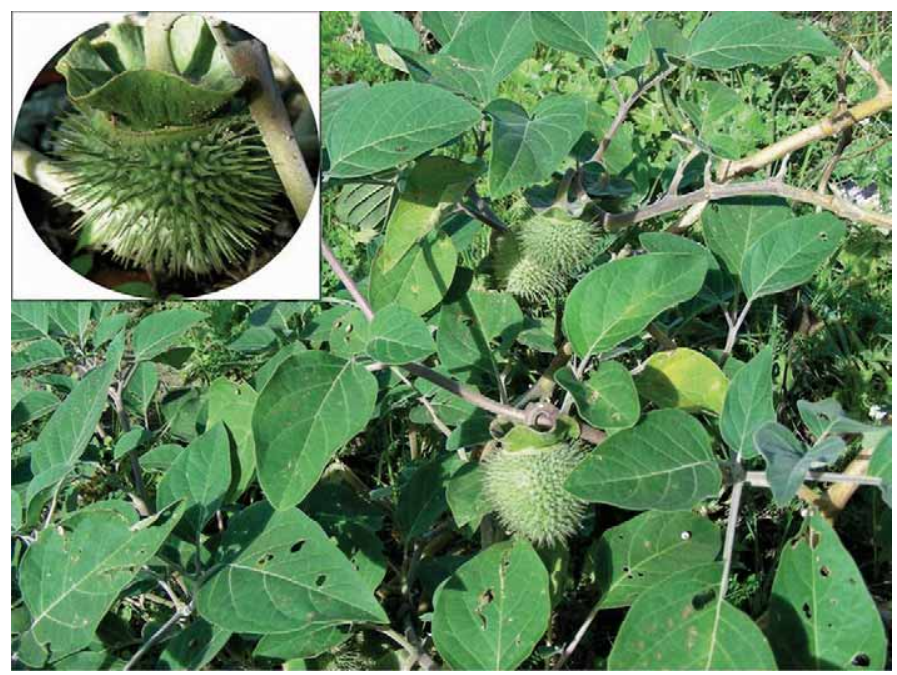

Fig. 4. Datura innoxia, habitus and fruits (photo: D. Stešević).

ity several alien species were present: Phytolacca americana L., Chenopodium multifidum L., Datura stramonium, Conyza albida Spreng. and Conyza canadensis (L.) Cronquist. Monitoring of this population since May 2010 to November 2012 did not show any significant invasion into the surrounding hinterland. This year another population of Datura innoxia was found in Dobre Vode, $25 \mathrm{~km}$ away from the first locality.

This annual plant originates from Central America and is widespread in Europe. Although Flora Europaea (MoORE 1972) does not include species from the Balkans, some literature sources indicate that this species has been known from the Sofia district (Bulgaria) since 1933 (GREUTER and RAUS 2005). In Greece, the first documented voucher was by A. Yannitsaros in October 1966. He collected plants from a rubbish-tip on waste ground on the South Peloponnesian island of Kithira (published in YANNITSAROS 1998: 88, as Datura metel L.). In October 1972 the plant was recorded from the east coastal mainland of Greece (Nea Makri in Attikis, Greuter 10614, ATH). In Crete, Datura innoxia has been recorded from roadsides in the district of Merabellou; it was collected by A. Hansen in October 1973 (Hansen 1063, C). Later it was recorded from the Ionian island of Kerkira, N, S and E Peloponnese, NE Aegean islands of Thasos and Samothraki, E Aegean islands and the Cyklades. In Greece the plant is mainly distributed in coastal places, along roads, on waste ground, in gardens, etc. In Arkadias it has been found further inland and at a higher altitude $(150 \mathrm{~m})$ on waste ground by a fertilizer plant (Kit Tan and Strid 18710, herb. Strid). The species was reported in Croatia approximately 30 years ago (Hećimović 1981). Populations of Datura innoxia have spread not only to a number of locations in the littoral region of Croatia but also within the continental parts (HEĆIMOvić 1982, ŠTAMOL and MARKOVIĆ 1985, FRANJIĆ 1993, PANDŽA and STANČIĆ 1990), so the inland part of Montenegro should not be excluded from the monitoring of the spread of this species in future. Datura innoxia spreads along roads, in courtyards, gardens and in ruderal vegetation as an ergasiophygophyte (PANDŽA et al. 2001). In agricultural and forest lands where it appears as the principal weed, Datura innoxia may cause extensive and expensive damage (TRINAJSTIĆ et al. 1993, FRANJIĆ 
and TRINAJSTIĆ 1996, Franjić et al. 1998). Up to now, in Montenegro this species has not been reported for cultivated land, but due to its capacity to invade such habitats it can be considered a potential threat.

Our records show that Datura innoxia is spreading in the Mediterranean part of the Balkan Peninsula and thus can be expected in Albania as well.

Voucher specimens:

MONTENEGRO: Long Ulcinj Beach N 41 53' 52.2”, E 19 17' 58.2”, 15 m a.s.1., waste ground (Caković, D., Stešević, D., 9.11.2012., TGU- 319395).

\section{Eclipta prostrata (L.) L.}

During the field survey in the hinterland of Long Ulcinj Beach, Eclipta prostrata (Fig. 5) was found at only one location (N 42 53'19.0" E 19 18'42.6”), ca $300 \mathrm{~m}$ inland, in the small ruderal patch in the humid dune slack zone (NATURA 2000 habitat - 2190, ass. Eriantho-Schoenetum nigricantis (Pignatti 1953) Géhu in Géhu et al. 1984). Part of the population was in a small water-filled depression, with water up to $10 \mathrm{~cm}$, while the remainder of the population was on humid sandy soil. Approximately 30 mature individuals were found. In addition to Eclipta L. numerous adventive species were present, indicating a strong anthropogenic influence at this site: Conyza canadensis, Paspalum paspalodes (Michx) Scribner, Euphorbia maculata L., Sporobolus poirettii (R. et S.) Hitchc, Oenothera biennis L., Xanthium italicum Moretti, Aster squamatus (Spreng) Hieron. Elements of native flora: Medicago arabica, Cynodon dactylon, Holoshoenus vulgaris, Potentilla reptans L., Lythrum salicaria L. As Long Ulcinj Beach hosts large numbers of migrating bird (it is one of the most Important Bird Areas of Montenegro, CZIP, 2008) we conclude that Eclipta prostrata was probably introduced to this locality by birds.

Eclipta is a small genus in the family Compositae (tribe Heliantheae), of which several species are distributed primarily in the New World and some in the Old World (UMEMOTO

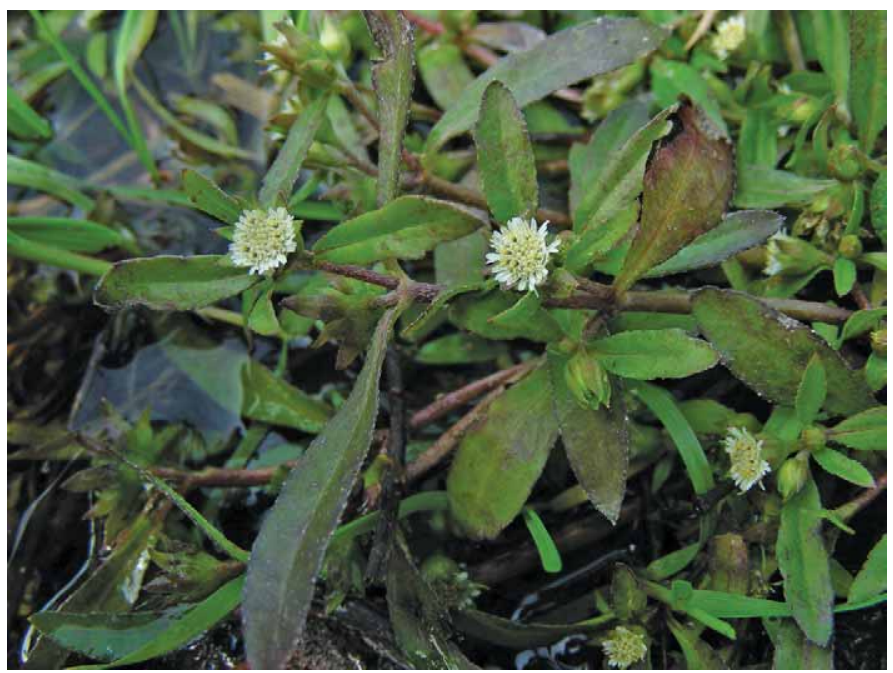

Fig. 5. Eclipta prostrata (photo: D. Stešević). 
and Koyama 2007). Currently there is only one species in Europe: Eclipta prostrata (EURO+MED 2006). This species is widely distributed across all continents, excluding Antarctica, and tends to remain in the tropics and sub-tropics, but can also be found in temperate regions (HoLm et al. 1977) and can therefore adapt to changing environmental conditions. It is most aggressively invasive in warm, low-lying areas with high rainfall but it can also tolerate saline conditions, higher altitudes and drier sites. Prefers full or partial sun and tolerates both fine and coarse-textured soils. Eclipta prostrata has low fertility requirements, high anaerobic tolerance, and low drought tolerance (USDA). Opinions about its origin differ significantly. TUTIN (1976) consider Eclipta prostrata native for tropical and warm-temperate America, while STONE (1970) suggested a probable Asiatic origin.

Up to 1976 in Europe this species was reported only for Italy, Spain and Portugal (TuTIN 1976). It has since appeared in Belgium, Bulgaria, Cyprus, Greece, Romania, Turkey, and Ukraine. (EuRO+MED 2006). In the Balkan Peninsula E. prostrata was collected in Greece for the first time in 2001, in a rice field south of Kalamata airport in Messinia, S. Peloponnese (RAUS and RAABE, 2002). A few years later it was recorded from the E. Aegean island of Rhodes (a collection by Ristow and collaborators on 10 January 2004, personal communication). In September 2010, it was recorded from the island of Poros, off the coast of the E. Peloponnese in the SE part of the main town, on a coastal embankment near an irrigation channel (SEREGRIN and KIT TAN, personal communication). In Cyprus it was reported by DELla and IATROU (1995). Since then it has shown a trend of slow expansion along irrigation channels and cultivated land and its status in Greece is now naturalized non-invasive species (HAND 2009). In Bulgaria E. prostrata was first reported in 2007, close to the riverbank in vegetation which belongs to the class Isoeto-Nanojuncetea Br.-Bl. et Tuxen 1943 (TzONEv 2007). Up to now this species has not been found in any neighboring Balkan countries, so this find represents the new western boundary of its Balkan distribution and illustrates the tendency of this species to spread within the Mediterranean region.

Somewhat surprisingly, this rather unsightly species has been used in various parts of tropical and sub-tropical regions like South America, Asia, Africa, as a medicinal and edible plant (Bown 1995, Cheryl 2007, KHAN and KHAn 2008, Dalal et al. 2010).

Voucher specimens:

MONTENEGRO: Long Ulcinj Beach N 42 53' 19.0” E 19 18' 42.6”, 2190 Humid dune slack, ruderal patch (Caković, D., Stešević, D., Vuksanović, S., 9.11.2012., TGU319396).

\section{Acknowledgements}

The authors would like to thank Dr Karin Persson for valuable help in identification of Colchicum cupanii subspecies, and discussions about its ecology and distribution, and Dr Anton Dresher for help with the literature. The field investigation that took place in the autumn of 2012 was funded by UNDP office in Montenegro (project number MNE 12-057).

\section{References}

Blečić, V., Pulević, V., 1979: Some new data in the flora of Montenegro. Glasnik Republičkog Zavoda za Zaštitu Prirode i Prirodnjačkog Muzeja 12, 189-193. 
Bown, D., 1995: Encyclopedia of herbs and their uses. Dorling Kindersley, London.

Cheryl, L., 2007: Comparison of plants used for skin and stomach problems in Trinidad and Tobago with Asian ethnomedicine. Journal of Ethnobio and Ethnomedicine 3, 1-12.

CZIP, 2008: IBA Areas in Montenegro. Retrieved March 9, 2013 from http://www.birdwatchingmn.org/index.php?lng=cg\&page $=61 \#$ plaza

Dalal, S., Kataria, S. K., SAStry, K., Rana, S. V. S., 2010: Phytochemical screening of methanolic extract and antibacterial activity of active principles of hepatoprotective herb Eclipta alba. Ethnobotanical Leaflets 14, 248-58.

Della, A., Iatrou, G., 1995: New plant records from Cyprus. Kew Bulletin 50, 387-396.

Euro+MED, 2006: Euro+Med PlantBase - the information resource for Euro-Mediterranean plant diversity. Retrieved March 9, 2013 from http://ww2.bgbm.org/EuroPlusMed

EUROPEAN COMMISSION DiRECTORATES GENERAL, 2007: Interpretation manual of European Union habitats, 2007. European Commission Directorate General for the Environment Nature and Biodiversity, Brussels.

FrANJIĆ, J.,1993: New findings of Datura innoxia Miller (Solanaceae) in Croatia. Acta Botanica Croatica 52, 97-100.

FrAnJiĆ, J.,TRinAJSTIĆ, I., 1996: Current state of the distribution of the species Datura inoxia Miller (Solanaceae) in Croatia. Fragmenta phytomedica et herbologica 24, 5-9.

Franjić, J., Trinajstić, I., ŠKVORC, Ž., 1998: A contribution to the knowledge of the spreding of some neophytes in Croatia. Fragmenta Phytomedica et Herbologica 26, 5-17.

Greuter, W., Raus, T., 2005: Med-Checklist Notulae, 23. Willdenowia 35, 55-64.

Guterman, W., 2012: A note on Pteris vittata L. (Pteridaceae) in Montenegro. Acta Botanica Croatica 71, $371-374$.

HAND, R., 2009: Supplementary notes to the flora of Cyprus VI. Willdenowia 39, 301-325.

Hećimović, M., 1981: Report and the analysis of the island of Šipan flora. Acta Botanica Croatica 40, 205-227.

Hećimović, S., 1982: Flora on the islands of Lokrum, Bobara and Mrkan. Acta Botanica Croatica 41, 155-170.

Holm, L. G., Plucknett, D. L., Pancho, J. V., Herberger, J. P. 1977: The World's Worst Weeds: Distribution and Biology. University Press of Hawaii, Honolulu.

IUCN, 2003: Guidelines for application of IUCN red list criteria at regional levels, 3.0. International Union for Conservation of Nature and Natural Resources, Gland and Cambridge.

IUCN, 2011: Guidelines for application of IUCN red list categories and criteria, 9.0. Retrieved March 11, 2013 from http://www.iucnredlist.org/documents/RedListGuidelines. pdf

Khan, A. B., KhAn, A. A., 2008: Ethenomedicinal use of Eclipta prostrata Linn. Indian Journal of Traditional Knowledge 7, 316-320.

Lakušić, D., Stevanović, V., Bulić, Z., Jovanović, S., Tomović, G., Vukojičić, S., 2004: Floristical and chorological contribution to the vascular flora of Montenegro. Glasnik Republičkog Zavoda za Zaštitu Prirode 27-28, 33-42. 
Moore, D. M., 1972: Datura L. In Tutin, T. G., Heywood, V., Burges, N. A., Moore, D. M., Valentine, D. H., Walters, S. M.,Webb, D. A., (eds.), Flora Europaea 3, 200-201. University Press, Cambridge.

Mujović, A., 1994: The xerohalophytic sand communities of the Long beech. Glasnik Instituta za Botaniku i Botaničke Bašte Univerziteta u Beogradu 28, 147-157.

PANDŽA, M., StAnČIĆ, Z., 1990: New localities of the species Datura innoxia Miller and Solanum elaeagnifolium Cav. (Solanaceae) in Croatia. Natura Croatica 8, 117-124.

PANDŽA, M., Franjić, J., Trinajstić, I., ŠKVORC, Z., StanČIĆ, Z., 2001: The most recent state of affairs in the distribution of some neophytes in Croatia. Natura Croatica 10, 259-275.

Persson, K., 2007: Nomenclatural synopsis of the genus Colchicum (Colchicaceae), with some new species and combinations. Botanische Jahrbücher für Systematik, Pflanzengeschichte und Pflanzengeographie 127, 165-242.

Petrović, D., SteŠEvić, D., 2011: Shift of the western boundary of the distribution area of Micromeria cristata (Hampe) Griseb. and Steptorhamphus tuberosus (Jacq.) Grossh. Acta Botanica Croatica 70, 259-267.

Petrović, D., Vuksanović, S., 2005: A contribution to the knowledge of flora of Ulcinj district. Natura Montenegrina 4, 17-21.

PignatTi, S., 1982: Flora d' Italia, 1-3. Edagricole, Bologna.

Pulević, V., 1976: Some rare and new plants in the flora of Montenegro. Glasnik Republičkog Zavoda za Zaštitu Prirode i Prirodnjačkog Muzeja 9, 99-102.

Pulević, V., 2005: Material for the vascular flora of Montenegro. Podgorica: Posebno izdanje Republičkog zavoda za zaštitu prirode Crne Gore.

RAUS, T., RAABE, U., 2002: Paddy weeds - a neglected subject of Greek floristics [in Greek with English abstract]. In KAMARI, G. et al. (eds.), Proceedings 9 Panhellenic Scientific Conference, Hellenic Botanical Society, 290-300.

Rohlena, J., 1942: Conspectus Florae Montenegrinae. Preslia, 20-21, 1-506.

Rouy, MG., 1905: Remarques sur quelques Colchiques. Bulletin de la Societe Botanique de France 52, 641-646.

SteŠević, D., Petrović, D., Bubanja, N., Vuksanović, S., Biberdžić, V., 2008: Contribution to the flora of Montenegro. Natura Montenegrina 7, 605-631.

Stevanović, V., Jovanović, S., LAKušić, D., Niketić, M., 1995: Diversity of vaskular flora in Yugoslavia with a list of internationnaly importnt species. In STEVAnOvić, V., Vasić, V., (eds.), Biodiversity of Yugoslavia [in Serbian], 183-217. Biološki fakultet and Ecolibri, Beograd.

Stone, B., 1970: The Flora of Guam. Micronesica, 6. Guam University Press.

ŠTAmol, V., MARKović, LJ., 1985: A contribution to the flora of Brač island. Acta Botanica Croatica 44, 99-106.

TRINAJSTIĆ I., 1989: A contribution to the knowledge of the vegetation of coastal sandbars class Ammophiletea B.- B1. et Tx 1943 in the Montenegrian coast. CANU - Glasnik Odjeljenja Prirodnih Nauka 7, 45-51.

TrinAJSTić, I., PAVletić, Z., Franić, J., LIBER, Z.,1993: Contribution to the knowledge of the neophytic flora of Makarska littoral (Dalmacija, Hrvatska). Fragmenta phytomedica et herbologica 21, 57-62. 
Tutin, T. G., Heywood, V., Burges, N. A., Moore, D. M., Valentine, D. H., Walters, S. M.,WebB, D. A., (eds.) 1972: Flora Europaea 3. University Press, Cambridge.

Tutin, T. G., 1976: Eclypta L. in Tutin, T. G., Heywood, V., Burges, N. A., Moore, D. M., Valentine, D. H., Walters, S. M.,WebB, D. A., (eds.). Flora Europaea 4, 141. University Press, Cambridge.

Tutin, T. G., Heywood, V., Burges, N. A., Moore, D. M., Valentine, D. H., Walters, S. M.,WebB, D. A., (eds.) 1976: Flora Europaea 4. University Press, Cambridge.

Tzonev, R., 2007: Eclipta prostrata (Asteraceae): a new alien species for the Bulgarian flora. Phytologia Balcanica 13, 79-80.

Umemoto, S., Koyama, H., 2007: A new species of Eclipta (Compositae: Heliantheae) and its allies in eastern Asia. Thai Forest Bulletin (Botany) 35, 108-118.

UsDA. ARS, National Genetic Resources Program. Germplasm Resources Information Network - (GRIN). National Germplasm Resources Laboratory, Beltsville, Maryland. Retrieved March 9, 2013 from http://plants.usda.gov/java/nameSearch?keywordquery= eclipta + prostrata\&mode $=$ sciname $\&$ submit. $x=6 \&$ submit. $y=7$

Vuksanović, S., Petrović, D., 2007: The occurrence of Kickxia cirrosa (L.) Fritsch in Montenegro supports the earliest of this species for the Balkan peninsula. Bocconea 21, 201-205.

YanNitsaros, A., 1998: Additions to the flora of Kithira (Greece) I. Willdenowia 28, 7794. 